\title{
Resisting ruination: resource sovereignties and socioecological struggles in Cotopaxi, Ecuador
}

\author{
Tristan Partridge ${ }^{1}$ \\ University of California, Santa Barbara, USA
}

\begin{abstract}
This paper examines coordinated community responses to the deployment of controversial technologies by broccoli plantations in Cotopaxi province in Ecuador's central highlands. It studies the influence of enduring structures of inequality that delimit the distribution of land and water in the region - the effects of what Ann Stoler calls imperial debris within ongoing processes of ruination. It considers the socioecological struggles mobilized to address these processes in terms of resource sovereignties - shifting assemblages of rights and relations between land, identity, ecology and social justice. The technologies in question - acetylene 'cannons' designed to disperse clouds and thus prevent damage to crops from hailstones - were locally disruptive to weather patterns, agriculture, and everyday life. In collaboration with the regional offices of Ecuador's national Indigenous Movement, affected communities from across the region campaigned - in the streets and in the courts, and ultimately with some success - to outlaw these technologies of appropriation. Although the initial case was settled in 2010, new suspicions emerged in early 2016 as some community members again blamed the plantations for an unseasonable drought, alleging they had found new technologies to use in the destruction of clouds. Reading the cannons as forms of rubble (Gordillo 2014) focuses our attention on how and why these abandoned technologies re-emerged as a source of conflict in the region and exerted unexpected influence on responses to drought conditions. I suggest these claims, counterclaims and subsequent struggles not only reveal the persistence of processes of ruination and of resistance to them but also expose the fragility within apparently immutable political systems and destructive landscapes.
\end{abstract}

Key words: environment, Ecuador, technology, ruination, rubble, water

\section{Résumé}

Cet article examine les réponses coordonnées de la communauté au déploiement de technologies controversées par les plantations de brocolis dans la province de Cotopaxi dans les hauts plateaux centraux de l'Équateur. Il étudie l'influence des structures durables d'inégalité qui délimitent la répartition de la terre et de l'eau dans la région - les effets de ce que Ann Stoler appelle «débris impériaux» dans les processus de ruine en cours. Il considère les luttes socioéconomiques mobilisées pour aborder ces processus en termes de souveraineté des ressources - mouvements d'associations de droits et de relations entre la terre, l'identité, l'écologie et la justice sociale. Les technologies en question - les canons d'acétylène conçus pour disperser les nuages et ainsi prévenir les dommages causés aux récoltes par les grêlons - perturbent localement les habitudes météorologiques, l'agriculture et la vie quotidienne. En collaboration avec les bureaux régionaux du Mouvement indigène national de l'Équateur, les communautés touchées de toute la région ont fait campagne - dans les rues et dans les tribunaux, et finalement avec un certain succès - pour interdire ces technologies d'appropriation. Bien que le cas initial ait été réglé en 2010, de nouveaux soupçons sont apparus au début de 2016, car certains membres de la communauté ont accusé les plantations d'une sécheresse intempestive, en prétendant avoir trouvé de nouvelles technologies à utiliser dans la destruction des nuages. La lecture des canons en tant que forme de décombres (Gordillo 2014) met l'accent sur la façon dont et pourquoi ces technologies abandonnées ont réapparu comme source de conflit dans la région et ont exercé une influence inattendue sur les réponses aux conditions de sécheresse. Je suggère que ces revendications, les contre-revendications et les luttes subséquentes révèlent non seulement la persistance des processus de ruine

\footnotetext{
${ }^{1}$ Dr. Tristan Partridge, Postdoctoral Researcher, Department of Anthropology, University of California, Santa Barbara, CA, 93106-3210, USA. Email: tristan.partridge "at" ucsb.edu. Funding is acknowledged from the University of Edinburgh. This is the third article in Javiera Barandiarán and Casey Walsh (eds.). 2017. "Production/destruction in Latin America", Special Section of the Journal of Political Ecology 24: 716-800.
} 
et de résistance à eux, mais aussi ils exposent la fragilité dans des systèmes politiques apparemment immuables et des paysages destructeurs.

Mots clés: environnement, Équateur, technologie, ruine, décombres, eau

\section{Resumen}

Este artículo examina las respuestas comunitarias coordinadas frente a la utilización de tecnología controversial en las plantaciones de brócoli en la provincia de Cotopaxi, en la zona montañosa central de Ecuador. Se estudia la influencia de estructuras duraderas de desigualdad que delimitan la distribución de la tierra y el agua en la región -los efectos de lo que Ann Stoler llama restos imperiales, dentro de los procesos de ruina. El artículo considera las luchas socioecológicas movilizadas para abordar estos procesos en términos de soberanía de recursos -moviendo ensamblajes de derechos y relaciones entre tierra, identidad, ecología y justicia social. Las tecnologías en cuestión -“cañones” acetileno diseñados para dispersar las nubes para que el granizo dañe las cosechas- resultan perturbadoras para los patrones climáticos locales, la agricultura, y la vida diaria. Comunidades afectadas a lo largo de la región en colaboración con las oficinas regionales del Movimiento Indígena nacional de Ecuador, hicieron una campaña -en calles y cortes, finalmente con algo de éxito- para prohibir estas tecnologías de apropiación. Aunque el caso inicial se estableció en 2010, a inicios del 2016 surgieron nuevas sospechas cuando miembros de una comunidad culparon algunas plantaciones por una inexplicable sequía, argumentando que encontraron nuevas tecnologías para la destrucción de nubes. Con una lectura de los cañones como escombros (Gordillo 2014), ponemos la atención en cómo y por qué estas tecnologías abandonadas resurgieron como una fuente de conflicto en la región y ejercieron una influencia inesperada en las respuestas a las condiciones de la sequía. Sugiero que estas demandas, contrademandas y consiguiente lucha no solamente revelan la persistencia de los procesos de ruina y de resistencia a estos, sino que también revelan la fragilidad dentro de unos aparentemente inmutables sistemas políticos y paisajes destructivos.

Palabras clave: medio ambiente, Ecuador, tecnología, ruina, escombro, agua

\section{Introduction}

In May 2011, Ecuador's most active volcano began erupting again. Tungurahua is located 30-40 miles south of the indigenous community of San Isidro (where this fieldwork was based), and so posed no immediate threat to residents there - but it was clearly visible on the horizon and its rumblings could be heard, and felt, underfoot. I was with Don Jorge (a veteran of community affairs in San Isidro) when we heard what sounded like the sound of a distant plane, only it seemed to be emanating from the ground. He read my wonder as alarm: "Not us, we're not scared by it. She lets us know she's there, part of the Earth - and so: Mama Tungurahua." Then he added: "Many times in the past, like this. Another time, though, we also thought we had heard Mama Tungurahua - we heard, we listened, but there was nothing you could see. We heard explosions. We had no idea. And what was it? It was those cannons!"

Those inexplicable sounds, made by 'those cannons', turned out to be emanating from some new installations constructed on the nearby Hacienda Selva Alegre, a broccoli-for-export plantation run by agroindustrial operator Empresa Nintanga. This was at the start of 2009, and these events marked the beginning of a mobilization and campaign against the plantations that would grow to involve communities from across Cotopaxi province - culminating in a successful legal case that shut the cannons down. Seven years later - early 2016 - and tensions once again flared between the hacienda estates and neighboring communities. As the region went through a prolonged period of low or zero rainfall, local farmers' groups and indigenous organizations mobilized to demand the plantations prove they were not responsible for inducing the drought conditions as a result of using other forms of cloud dispersal technologies.

This article looks at the ongoing impact on socioecological relations in Cotopaxi of what Stoler calls imperial debris or colonial ruins - enduring structures of domination that unevenly curtail agency and affect social and environmental well-being through processes of ruination (Stoler 2008). It examines how environmental conflicts, and these particular instances of ruination, emerge amid the erosion of resource sovereignties - the reconfiguration of differential powers to access, control or attribute value to natural 
resources, typically limiting the reach of localized forms of governance and favoring more concentrated, less equitable arrangements for distribution and management (Acosta 2010; McNeish 2010). By contrast, socioecological struggles mobilized to resist these trends involve reasserting sovereignty as a principle of social justice (Carrera 2010) - mobilizing beyond straightforward political opposition in order to keep physical and political spaces open for sustaining collective practices (Kenrick 2011; Partridge 2015). Describing moments of intensified struggle, and engaging the concept of rubble to interrogate the production of destructive landscapes and conflict in the present (Gordillo 2014), the paper highlights some of the continuing social and historical processes in the region that create and exacerbate contemporary inequalities (Pellow 2000).

This work complements political ecology's established focus on the "production of unevenness" by also studying the production of cooperation, redistribution and non-exploitation (Burke and Shear 2014). It examines the political ecology of resource use in a country where national level dynamics have been widely scrutinized and subsequently characterized by: (1) the ownership and management of resources being considered national concerns and patrimony, and (2) the democratic voice and active dissent of local or indigenous groups being aggressively curbed (Bebbington 2009). In the events studied here, as elsewhere (see for example Hoelle 2017), these dynamics of inequality, expansion and impunity are directly driven not solely by state agencies but by non-state actors, including agro-industrial corporations, historical elites and large local landholders (Mccreary and Lamb 2014). The social and ecological geographies of highland Ecuador are acutely marked by histories of resource inequalities, discriminatory agrarian policies, environmental degradation and precarious livelihoods (Bebbington et al. 2013; Bretón 2015; Partridge 2016a; Peña 2015). Experiences from these socioecological struggles in Cotopaxi simultaneously reflect and disrupt significant political shifts at regional and national scales, including Constitutional reform ratified in 2008.

Developing these themes, what follows is divided into: (1) an account of the original campaign against the plantations and its context; (2) a critical engagement with concepts of ruination and resource sovereignties as they apply to events in Cotopaxi; (3) details of the re-emergence of tensions between plantations and nearby communities. The conclusion reflects on the disruptive presence/absence of different kinds of ruins and rubble, and on how examining efforts to resist ruination and restore resource sovereignties expands our understanding of diverse socioecological struggles.

\section{The anti-cannons campaign}

Cotopaxi province covers a range of landscapes in central Ecuador, including high-altitude páramo moorland, active volcanoes, semi-arid agricultural plots across mountainous foothills, as well as larger expanses of flatter, fertile farmland located on the inter-Andean plain. As highlighted elsewhere (e.g. Arce et al. 2015; Partridge 2016b), the concentration of land across the region coupled with the unequal distribution of natural resources such as water reflect divisions established in the colonial era - and land reform measures enacted in the mid-twentieth century have had minimal impact in terms of addressing these imbalances. In 2009, large hacienda farm estates made up $2 \%$ of the total number of registered farms in Cotopaxi and yet covered almost half of all available agrarian land (Flores 2009). Occupying the most accessible and most profitable land in the region - previously occupied by colonial hacienda estates - today's large-scale agricultural enterprises have been able to capitalize on their historically established settlements and water concessions to build commercial enterprises responsive to market imperatives.

Ecuador is one of a number of countries in the global south responding to increased globalization of agriculture since the 1990s by specializing in non-traditional exports (Le Gall 2009). Over the same timeframe, Ecuador has shifted development strategy from state-led programs to state-promoted involvement in global production chains (Latorre et al. 2015; Robinson 2009). It was in 2008 that estates in the Alpamalag valley transformed themselves from dairy farms catering largely to the domestic market into plantations growing exclusively for the export market (Arce et al. 2015; Houtart and Yumbla 2013). In this case, the crop being exported is broccoli (Brassica oleracea var. italica).

In a country that is one of the world's key exporters of broccoli, recent estimates indicate that about two thirds of Ecuador's exports of the crop have originated in Cotopaxi province (GADPC 2015). Industry 
representatives have recently promoted increased processing and freezing capacities in the highlands, capitalizing on Ecuador's ability to grow broccoli year-round, and expanding exports not only the US but also Russia, as well as Japan, Europe, UAE, Canada, and Chile (FP 2015). Moreover, support for large-scale agribusiness has grown since 2007 under the Correa government (Clark 2015). The expanding broccoli market has also received attention from international development groups with the aim of increasing 'small farmer' participation - though not in Cotopaxi province where large producers dominate (USAID 2015). Broccoli requires large amounts of water and consistent supplies are needed to meet regular export contracts. Industrial irrigation in Cotopaxi is facilitated by historic water rights that greatly limit the amount of water available to nearby indigenous and campesino farming communities (Partridge 2016b). In response to these inequalities, some communities have organized and accessed external support, enabling them to construct their own irrigation systems (Partridge 2016a). Others, however, are without the facilities to do so and consequently continue to struggle with soil erosion and land degradation. It was in this context of ongoing domination that attempts by plantation owners to control the skies - at the direct cost of neighboring communities - were met with widespread resistance.

When the mysterious bangs were first heard in 2009, those living nearby in the closest communities (Cinco de Junio and San Gerardo) found the noise deafening. In San Isidro, a mile further north within the Alpamalag valley, the unusual, regular detonations would startle livestock and horses, and for a while no one came up with an explanation. Tungurahua? The sounds were too regular, and there had been nothing on the news about volcanic activity. Gunshot? Too loud to be just a regular gun. Some kind of construction work? There were no new structures nor machinery anywhere to be seen. Over subsequent weeks, these questions turned to rumors: the plantations were to blame.

Concerns were fuelled by the coincidence of these sounds with a prolonged dry period - these months would usually see regular rainfall and yet that year the ground was getting dry and crops were beginning to suffer stunted growth. The local union of indigenous communities, OPIJJ', held an assembly meeting to clarify the issue and to establish what was to be done - drawing together testimony from residents in affected communities and also, crucially, from a number of residents from more distant communities not directly affected. This included Yacubamba, the largest community-member of OPIJJ (at almost 200 households), located some 3.5 miles $(5.6 \mathrm{~km})$ away in a different valley, shielded from events by a low range of hills on the western edge of the Alpamalag valley. A small number of Yacubamba residents were seasonal workers in the broccoli plantations and they confirmed the source of these sounds: the plantations had installed cañones antigranizo.

'Anti-hailstone cannons' are devices that ignite a charge of acetylene gas in their blast-chamber base and this explosion releases a pressure wave which is designed to disrupt the formation of hailstones in the atmosphere by creating a 'cavitation' effect. Hailstones could damage the leaves and harvest of Hacienda Selva Alegre's main crops (broccoli, romanesco broccoli and cauliflower). Anti-hailstone cannons offered the plantation-owners the promise of reducing this damage. The cannons - unlicensed and constructed without any prior consent, nor permission from provincial environmental agencies - also disturbed life in neighboring communities. Not only due to the 'unbearable' noise but also, and more importantly according to the subsequent legal claim, because the cannons disrupted and diverted rainfall patterns in the surrounding area.

Nearby, affected communities began organizing open planning meetings, held weekly by OPIJJ. Responses were coordinated at the provincial level by MICC (the Indigenous and Campesino Movement of Cotopaxi), and benefited greatly from the support an organization of that size could offer, especially information on the correct state officials to raise the issue with, legal advice, and media contacts information that they shared from their offices in Latacunga, the provincial capital.

Empresa Nintanga also had plantation fields further north in Cotopaxi and, in total, more than thirty campesino and indigenous communities were affected across the province. Through MICC, the numbers of

\footnotetext{
2 OPIJJ stands for Organización del Pueblo Indígena de Jatun Juigua /The Organization (formerly: 'Union') of Indigenous Communities in Jatun Juigua. Within the national Indigenous Movement, OPIJJ is an OSG (organizaciones de segundo grado, second-tier organization). Taken together, OSGs form third-tier federations at the province level: in this case, OPIJJ is a member of MICC (Movimiento Indígena y Campesino de Cotopaxi /the Indigenous and Campesino Movement of Cotopaxi Province).
} 
people involved in the campaign grew and two protest marches were planned. One was spearheaded by OPIJJ and led by members of affected communities in the Alpamalag valley, and received local media coverage. Two weeks later, following sustained campaigning work by MICC and affected community councils, the largest march was held, with hundreds of people present - some travelling from parishes in the neighboring canton of Saquisilí, not close to the plantations themselves - and subsequently covered by the national media. The use of anti-hailstone cannons was, for many people in each of these areas, yet another example of the invasive and continuing presence of the haciendas (Lyons 2006). Recalling the campaign, Rocío Simaluisa from San Isidro saw these cannons as an extension of the haciendas' dominance. She asked, "You've seen what they do... with the land. Their huge farms. They think the clouds, the clouds in the sky are theirs too?"

In Cinco de Junio, located right beside the Hacienda Selva Alegre plantation, community leader Esmeralda Yasig had long been engaged in campaigns for more extensive community water rights, including gathering data on differential access to irrigation among local farmsteads of different sizes (Partridge 2016b). As she put it:

Land Reform then, and today: the new Constitution, in 2008. These changes are supremely important. But who listens to them? You've heard about the brocoleros (broccoli plantations) blasting the sky with high-pressure gas, blasting away the rain. We had to fight. Now, these days... it's not allowed for haciendas to exist, but they're still here - look [points out across the plantations] - haciendas are still here, they just changed the name, now they're empresas (businesses/companies).

Following the marches and subsequent media coverage, the campaign secured a local magistrate ruling that ordered Nintanga to refrain from further use of the anti-hail cannons. This initial ruling applied just until Nintanga had applied for the requisite licence. It was only after a legal case had been pursued - also coordinated by MICC, backed up by Impact Reports from the regional Environmental Agency, and eventually ratified by a provincial judge - that Nintanga was banned from using the cannons at all.

The legal case made extensive use of Constitutional rights pertaining to Buen Vivir - a Spanish translation of the Kichwa concept, Sumak Kawsay (or 'Harmonious Living'), adopted by the Ecuadorian government in 2008 as a policy framework for development and social welfare. The case detailed seven ways in which the activities of Nintanga contravened these recently codified constitutional principles. One drew on Article 14 of the Constitution which recognizes 'the right of the population to live in a healthy and ecologically balanced environment' - in order to ensure sustainability and Buen Vivir. Various factors that contravened the right to a healthy environment were listed: that the noise levels generated by the anti-hail cannons were in excess of permissible limits; that use of the cannons had led to climatic change and a reduction in rainfall; and also that the ongoing use of agrochemicals by Nintanga threatened the natural environment.

The case also cited Article 396 of the Constitution (similarly under the heading of Buen Vivir) which details the precautionary principle to be applied to policies and measures that impact directly, or indirectly, on the living environment: 'in case of doubt about the environmental impact of any action or omission, the State will adopt efficient and appropriate protective measures.' This element was particularly important given the contested causal links between the use of anti-hail cannons and a lack of rainfall.

The stated operation of the cannons was to stop the formation of hailstones, without necessarily dispersing clouds in the process. Although their effectiveness on either front is disputed, Nintanga clearly had enough faith in their efficacy to proceed with their investment. However, when approached by the press at the time, a representative from Nintanga pointed to exactly the uncertainty that surrounded their operation: "what the people from these communities [round here] are saying is not certain. The lack of rainfall is due to global warming [not the cannons]" (El Comercio 2009). The role of uncertainty here is important. The Constitution returns to the idea of the precautionary principle more than once. Article 427 clarifies that 'in the case of any doubt', policy must follow the course that most closely complies with an understanding of the constitution as a whole - that is, in support of Buen Vivir as a guiding principle for development. The theme 
is also found in Article 395: 'In the case of any doubt about the reach of legal regulation in environmental matters, regulation will be applied in the manner most favorable to the protection of Nature.' The anticannons campaign used Buen Vivir to successfully put a stop to the use of 'technologies of appropriation' technologies designed not to seize nebulous/aqueous resources for use within systems of production, but instead to control and redirect them.

Many of the constitutional principles of Buen Vivir are related to principles of sovereignty. In Article 385 (under the heading Buen Vivir) the 'national system of science, technology, innovation and ancestral knowledge' is not only to serve Nature, the environment, sovereignty and cultural diversity, it is also to support technologies that improve quality of life and contribute to the 'realization' of Buen Vivir itself. Under the same heading, in managing biodiversity and the biosphere, duties of the state include prioritizing intergenerational responsibility (Article 400) and supporting technologies that do not jeopardize food sovereignty, ecological well-being or the fundamental right to water (Article 413). Under the heading Development Plan, Article 318 brings sovereignty and water governance together: water-use projects in productive enterprises require state authorization and should support food sovereignty. Thus, while the anticannons legal case depended heavily on Buen Vivir - to the point where it is hard to imagine how it could have proceeded without these recent additions to the constitution - the many measures that support diverse forms of sovereignty in the same document could also have formed a basis for the case, as means for counteracting the actions of the plantations.

\section{Ruination and resource sovereignties}

The anti-cannons campaign demonstrates legal strategies that were successfully deployed at a particular moment in time to limit local acts of expansion on the part of agricultural estates. However, broccoli production in this part of Cotopaxi also reflects a broader social context in the Alpamalag valley marked by ongoing inequalities and structural relations established during colonial rule, as in many places across the region. Throughout Ecuador, people negotiate different patterns of governance, landholding, religion, labor, and race relations that adopt or resemble colonial forms (Lane 2003). National processes of 'modernization' have repeatedly been seen as ineffective in reducing the stifling effects of political, religious, and economic structures that have marginalized and afflicted indigenous populations in particular (Colloredo-Mansfeld 2009; Partridge 2016a; Rahier 2003). Such persistence has been a driving force in mobilizations that seek to reverse patterns of marginalization and dispossession - what for some is seeking to overcome colonial legacies or to "remake" a social world that has been "badly crafted" (Whitten and Whitten 2011).

Analytical projects to historicize forms of division, extraction, corruption and exploitation have questioned which of Ecuador's "presumed colonial legacies" are directly rooted in nineteenth and early twentieth century histories and which are linked to older global processes - arguing that the concentration of wealth and natural resources in agriculture (particularly in the highlands) reflects a "genuine" colonial legacy rather than one that is merely apparent or "reconstituted" (Lane 2003: 88). As an act of expansion on the part of the haciendas who benefit from the concentration of land and water resources in Cotopaxi, the installation of anti-hailstone cannons in many ways both testifies to and is made possible by such 'genuine' legacies. However, identifying legacies or establishing their taxonomy does little to help understand their ongoing effects on lived experience in specific locations, a task that requires examination of how different legacies operate and endure.

Some scholars argue that the idea of colonial legacy can obscure from view more recently introduced systems of inequality or assume a universalism to structures of domination that are experienced very differently across locations (Stoler 2008; Whitten 2003). Challenging the focus of colonial studies on practices of governance across European empires, Stoler proposes instead to examine imperial formations as political practices that produce and coerce populations according to particular notions of the common good diverse practices that operate by enforcing and responding to different "degrees of sovereignty" and shifting "gradations of rights" (Stoler 2006: 128). Stoler argues that this shift in focus - from empire and static legacies to imperial formations and shifting sovereignties - addresses the assumed universalism of a "colonial legacies" rubric by highlighting: (1) distinctions between residual political formations and those 
actively created or strengthened through contemporary political practices, and (2) the creativity and costs involved in people's attempts to extricate themselves from those practices (Stoler 2008: 196f.). With reference to events in Cotopaxi, this means paying attention not only to the historical political structures and "formal exclusions" that have created land and water inequalities, but also to the enduring "relations of force" that perpetuate those inequalities and sustain diverse processes of "decimation, displacement, and reclamation" (Stoler 2008: 193).

In place of legacies, then, we have "ruins of empire" and a focus on how people live among those ruins - an analytical engagement with the social relations that are either reinforced or denigrated by persistent relations of domination (Stoler 2008, 2013). These ruins are not remnant structures or desolate artifacts (Gordillo 2014) but are instead better thought of as integral components to continuing processes of ruination (Stoler 2008: 196). Ruination shapes the present both spatially and socially - causing loss of agency, impairing health, negating hope - facilitated by imperial formations as they affect gradations of sovereignty and enforce "racialized relations of allocations and appropriations" (Stoler 2008: 193f). For Stoler, the critical question is how imperial formations - these ruins that are "made" not "found" (p. 201) persist in the ruination of landscapes and lives. As we have seen, the deployment of anti-hailstone cannons epitomized historically established resource inequalities in Cotopaxi and their ongoing influence as colonial ruins. However, following Stoler, we need to look not only at particular events or instances of environmental conflict but also at how persistent processes of ruination are materialized. The Cotopaxi case reflects experiences in many other contexts: ruination occurs amid conditions that expedite and exacerbate the erosion of different sovereignties - resource sovereignties in particular.

The term resource sovereignties focuses attention on interwoven understandings of "territoriality, identity, rights, use and nature" (McNeish 2010: 19) - contested forms of sovereignty that are found at the heart of environmental conflicts and ruptured geographies (e.g. Laing 2015). At the national level, globalization processes have been paralleled by the "unbundling of sovereignty", directly challenging any idea of a stable relationship between the territory of a nation-state and (within that space) formalized control over political power and regulatory mechanisms (Aradhana 2006; Sassen 1998). In Ecuador, restoring national resource sovereignties has involved opposing economic policies that seek to limit state powers and deregulate financial markets (Martínez 2010), pursuing campaigns that seek to defend territory and patrimony against the deleterious effects of extractivism, and coordinating efforts to counteract the concentration of wealth and resources (Acosta 2010). Though broadly-defined and thus difficult to implement, "food sovereignty" as mentioned explicitly in the Constitution (and in the anti-cannons legal campaign, above) calls for the protection and redistribution of land and water, the diversification and localization of production, political recognition of indigenous lands and rights, as well as economic restructuring that favors existing joint ventures, indigenous initiatives, and the formation of new producers' cooperatives (Acosta 2010; Carrera 2010). ${ }^{3}$ Thus struggles to regain or reaffirm (resource) sovereignties not only involve claiming rights through political action but also aim at enabling cooperation among diverse beings and interests, while minimizing the influence of interests that work against such trajectories of change.

In Cotopaxi, processes of ruination are evidenced by the systemic, at times violent, erosion of resource sovereignties. Such erosion occurs through the dispossession of land and also as a result of the 'attritional' effects of political marginalization - for example from historical concessions that favor hacienda estates and limit access to water for many Alpamalag communities. In addition, broccoli is an extractive crop: not only is the produce exported from a province that suffers high levels of malnutrition, but along with

\footnotetext{
${ }^{3}$ The anti-cannons campaign is one example of how the broad scope of [food] sovereignty appearing in the 2008 Constitution - itself the result of action over many years on the part of indigenous and peasant movements - has been adopted by locally-specific struggles in defense of particular resources and practices. Organizing around food sovereignty has also fueled the growth of national organizing networks and government-social movement collaborations (Peña 2015). The constitutional focus on food sovereignty in Ecuador - restructuring the politics that govern food (and the resources required for food production) - is markedly different to indigenous and Indian struggles for sovereignty undertaken elsewhere in defense of territories. Such struggles for sovereignty and territory in North America, for example, have raised new questions of citizenship, indigenous political space and multiculturalism (Biolsi 2005) and have asserted the importance of cultural-territorial practices in interpretations of sovereignty (especially amid environmental conflicts) beyond those limited to the juridical-legal realm (Powell 2015).
} 
the crop, significant exports of locally-sourced water - required for production (Partridge 2016a) - are also exported. This is one of many forms of 'virtual' export of nature-as-product that has been resisted elsewhere in Ecuador (Latorre et al. 2015). The plantations in Cotopaxi are owned either by agricultural conglomerates or by landowning families linked to historical hacienda owners. As such, profits accrue outside communities living in areas of production. Similarly, decisions about land-use (what is grown, how, for who) are made elsewhere within the decision-making structures of the operating agencies, and the relatively small number of jobs created are precarious, low-paid, and frequently involve high levels of exposure to toxic agricultural pesticides and fertilizers.

However, just as imperial formations in Stoler's account are not fixed things but are "processes of becoming," so these continual dynamics of extraction and destruction in Cotopaxi have taken different forms at different times. The historical record charts regional histories of dispossession and domination (Weismantel 1998, Lyons 2006), and yet the scale and contours of local resource inequalities have shifted in response to revised priorities and market imperatives - as evidenced in the shift in land use from dairy ranching to broccoli export in the space of less than a year, a shift that presaged the intensification of waterrelated conflict in the region to the crop's water-intensive production and, with it, the further disruption of resource sovereignties for those indigenous and campesino communities living as neighbors to the broccoli plantations. Efforts to address such asymmetries consequently require not only campaigns for more access to productive resources but also the active dissolution of structures (particularly those that are made as colonial ruins) that threaten to further limit their use.

The cannons campaign reflected resistance to processes of ruination that nearby communities continue to endure. In what follows, I suggest that the cannons themselves, even in their absence, played a central role in the deep suspicion among affected communities of both the power and intent of the plantations. That is, we might consider these abandoned, now dismantled, technologies as forms of rubble: as objects that epitomize and expose the ongoing effects of ruins and ruination and the persistent erosion of resource sovereignties.

\section{Complicated cycles of nostalgia}

\section{Drought, fanesca, and an unexplained airplane}

The drought in Cotopaxi province in early 2016 followed periods of unseasonably dry weather coupled with particularly intense sunshine (Maisanche 2016a). Any moisture left in the soil from December rains had burnt off and a lack of significant rainfall persisted. The national Ministry for Agriculture (MAGAP, Ministerio de Agricultura, Ganadería, Acuacultura y Pesca) registered 550 hectares as affected lands in the province (Maisanche 2016b), and the regional governor called upon the national government to declare a state of emergency in the province (EI 2016). The National Institute of Meteorology and Hydrology (Instituto Nacional de Meteorología e Hidrología/INAMHI) reported at an early stage that the drought could go on for months (INAMHI 2016). The distilled account relayed here of re-emerging tensions and actions mobilized around these events in Cotopaxi is based on regional media sources.

Drought conditions prompted local food shortages and led to calls for more institutional support for small farmers whose livelihoods were acutely at risk (La Hora 2016). Media reports cited local concerns in the run up to Easter, specifically those affecting important annual festivities - referring to negative impacts on the harvest of diverse ingredients and the twelve different grains that characterize fanesca soup eaten during Holy Week (Maisanche 2016c). However, as rumors began circulating proposing alternative explanations for the drought, and as coordinated mobilizations subsequently began occupying streets in the provincial capital Latacunga, media coverage of the drought took a different focus - the claims and counterclaims of rural communities and plantations in the region.

Amid the drought, in February 2016, new forms of accusation against the plantations emerged, and the perennial theme of water scarcity resurfaced. Earlier reports documented not only the loss of seasonal crops, but also accounts of unusual activity in the skies that had concerned local residents - citing interviews with local campesino farmers such as 52-year old Carlos Pilatasig, a resident of a community known as the 
'garden' (huerto) of Latacunga located on the northern outskirts of town close to the airstrip: San Buenaventura (CN 2016a). He relayed how, "when clouds are gathering in the sky and turn black as if it's about to rain, right at that moment airplanes appear and immediately the clouds turn orange, and then turn white. The clouds break up and then no rain falls" (Maisanche 2016a).

As the dry weather continued, widely recognized as being worse than the previous year's unseasonable drought, similar reports accumulated in local meetings as well as in the media. The provincial branch of Ecuador's national Indigenous Movement (MICC) organized assemblies and later a press conference to clarify its position of solidarity with affected communities and to issue their demands for a formal investigation. Julio César Pilalumbo, president of MICC, described the complaints that farmers had come to his organization with: "at night it's possible to see lights from lasers, and in the afternoons between 4pm and $5 \mathrm{pm}$ a small plane is regularly spotted - we want to know what its destination is... if we don't get a response from the broccoli plantations around here - in Saquisilí, Latacunga and Pujilí - we'll have to protest in the streets" (CN 2016a).

At the same event, director of the Regional Environmental Council Vladimir Ortiz added his voice to the need for a thorough investigation, and a local councilor for Latacunga (Manuel Cocha) relayed rumors that plantation employees had themselves confirmed the haciendas were engaged in some form of cloud dispersal activities (CN 2016a). Also on the public record, Cotopaxi governor Jorge Guamán made explicit reference to the persistent memory of anti-hailstone cannons as a both a source of conflict between plantations and neighboring communities - previously challenged successfully by MICC and associates and as fuelling the more recent resurfacing of cloud-dispersal tools as an explanation for drought conditions (EI 2016).

As the story developed, although many actors made reference to the previous use of anti-hailstone cannons, no evidence of their more recent deployment had been encountered. The use of lasers was mentioned in some reports and accusations, but the focus mainly fell on the suspected use of planes and 'bombing' clouds with chemicals in order to disperse them (Expreso 2016; Illescas 2016; Maisanche 2016a).

Responses from industry representatives were swift and categorical. The executive director of APROFEL (Asociación de Productores Ecuatorianos de Frutas y Legumbres, Association of Ecuadorian Fruit and Vegetable Producers) wrote an open letter to a regional media outlet, Cotopaxi Noticias, denying "false rumors" regarding the alleged use of cloud dispersal techniques by the Association's members - citing the National Constitution (a document previously used against APROFEL associates) and highlighting the fact that associates would be subject to formal prosecution for any identifiable infringements (specifically of the rights of workers, farmers, Nature and the environment as codified in Articles 71, 72, 73, 74) (Gómez de la Torre 2016). While admitting in media interviews that the company Nintanga had used anti-hailstone cannons imported from New Zealand to Cotopaxi in 2009, he challenged those behind the recent allegations of malpractice to present any evidence, and addressed the call for information on the mysterious plane that had been spotted by adding how the Civil Aviation Authority would be able to confirm no plantations had used such airplanes (La Gaceta 2016).

Discussion of whether aviation-based techniques were feasible appeared only momentarily in the media. One report quoted a data technician at INAMHI (the National Meteorology Institute) who advised that aviation-based interventions in cloud formation already in operation elsewhere had been very difficult to apply accurately, were heavily dependent on local climate conditions, and were usually deployed to encourage rather than prevent rainfall - using silver iodide and carbon dioxide in cloud-seeding, not for cloud-destruction (Maisanche 2016a). Nonetheless, doubts did not emerge with any strength in the growing narrative about the possibility that planes could be used to disperse clouds.

\section{Marches, assemblies, and a triple threat}

"The people want water, and we must be heard!", "This year there'll be no fanesca!", "Down with the brocoleros!", "We want rain!" - hundreds of protestors gathered and raised their voices in the streets of Latacunga in early March 2016; residents, political leaders and farmers from indigenous and campesino communities across the province (Illescas 2016). Given the severity of the drought and its impacts on rural populations, the rally garnered widespread support. Rainfall, its absence, and contested explanations for that 
lack were not the only focal points, however - two other concerns were brought to the fore in the rally, in the speeches of those participating, and in the final document (a public claim against the plantations): issues around milk prices and the redistribution of water.

Alongside MICC in coordinating efforts for the rally were other political bodies working with smallscale farmers and milk-producers, including the Cotopaxi wing of the National Council of Rural Parish Governments (Conagopare), the Federation of Salcedo Farmers' Organizations (Fecos), and others who highlighted how drought issues facing their members were exacerbated by the recent trend of large-scale milk purchasers (usually pasteurizing companies) failing to pay small-scale producers the official market price for their product (Expreso 2016; Illescas 2016) - fixed nationally at US\$0.45 but at times only paying US $\$ 0.05$ (CN 2016b). Crucially, to these two demands concerning recent events there was added a third related to sustained inequalities in access to water for agriculture (a claim made all the more pertinent by drought conditions): calls for the redistribution of water rights according to more equitable principles. Other participants in the rally and signatories to the document included a number of local mayors, a member of the national assembly, an environmental engineer from Cotopaxi Technical University (UTC), regional environmental directors and the chair of local parishes (Expreso 2016).

The final document presented following the rally thus had three components. It called upon environmental authorities to investigate 'technically and scientifically' the causes of recent absent rains; demanded that the National Legislative Assembly reinforce rules governing the direct sale of milk by producers; and that administrative powers would be granted to Cotopaxi agencies to reassess and redistribute to small-scale producers the extensive water concessions currently granted to hacienda estates and agroindustrial producers (CN 2016b; Illescas 2016). These concerns in combination had brought together groups from all the major regions of Cotopaxi - Saquisilí, Salcedo, Pujilí and Latacunga - as signatories to the declaration that unless action was taken within 15 days, the 'public claim' against both the plantations and the environmental authorities would be escalated to the national courts (Creativos 2016; Expreso 2016)

Days later, the Provincial Council hosted a general assembly meeting to draw together these claims, their supporters and opponents, and to negotiate policy responses. More than 500 members of the public crammed the main provincial government offices during proceedings, as testimony was presented by representatives from numerous agencies including the Latacunga administration, provincial governments, the Risk Management Secretariat (Secretaría de Gestión de Riesgos / SGR), the National Institute of Meteorology (INAMHI), the Mayoral Offices of Pujilí, Salcedo and Latacunga, Municipal Councils, Latacunga Airport, the plantations and their operators' association (APROFEL), MICC, and above-mentioned farmers' groups - although some invitations extended to national agencies didn't result in attendance, including the Environmental Agency (MAE) and the Ministry of Agriculture (MAGAP) (Creativos 2016; El Telégrafo 2016).

The director of the Regional Environmental Council urged all those responsible within the provincial offices of the National Government to submit and process the information requested for all three public complaints: the study of the supposed 'cloud bombing' activities; the current state of play regarding enforcement of milk purchasing rules; and the request for revised forms of water redistribution across Cotopaxi - while also requesting that aviation records from the airport be released to confirm that no plantation-operated planes had been in use (Creativos 2016). The director of the industry group APROFEL was driven to restate the categorical statements cited above (Gómez de la Torre 2016), this time denying the recent use of all three technologies previously and presently rumored to have been deployed - [antihailstone] cannons, lasers, and small aircraft used for 'cloud bombing' (Maisanche 2016b) - going as far, with an air of exasperation, as to invite community leaders to come and inspect the plantation properties themselves for any signs of wrongdoing (El Telégrafo 2016).

However, driven in part by the lack of evidence to support the community claims, and informed by expert counsel ruling out the possibility of aviation-based cloud dispersal techniques, the meeting shifted focus mainly toward the plight of small farmers dealing with the severe drought, and an emphasis on possible forms of drought mitigation - including the redistribution of water. Patricio Bracero, a technician attending as a representative of INAMHI (the National Meteorology Institute), rejected the notion that Cotopaxi's drought had been caused by regional actions, and asserted instead that the absence of rain in the region was 
due to (global) climate change (El Telégrafo 2016). In light of climate-reduced access to water for agriculture among small farmers and indigenous communities, the need for politically induced mitigation measures increased - adding weight to the demand for revised redistribution of water resources across the province.

Although community groups have seen little evidence of water redistribution efforts, these protests and their expanded triple-front campaign had once again brought the issue back into the limelight, and plantation operators had gone on record stating that recent investments in irrigation systems, canals and water-holding tanks could lead to improvements for all farming groups in the area (Maisanche 2016b) measures that could, at least in theory, begin to lessen the effects of the ruination processes that dominate life in the region. Previous attempts on the part of plantations to extend their control of aqueous resources, including clouds, had thus laid the ground for future conflict. Seven years after their anti-hail cannons were first contested and closed down, another sustained campaign pursued by neighboring communities had driven the plantations to openly discuss inequalities in access to water that they have benefited from over many decades, bringing issues of water justice back in to the regional political domain.

\section{Conclusion: hybridized collectives of ecological rubble}

This paper has outlined two periods of conflict between plantations and neighboring communities in Cotopaxi province, highlighting the persistence of colonial ruins and their effects through processes of ruination. It has argued that seeing ruination as the erosion of resource sovereignties draws attention to critical elements of environmental conflicts both here and elsewhere, including the historical relations that maintain current patterns of socio-environmental inequality, and the absence of control many communities face in the kinds of socioecological impacts they are exposed to. At the same time, social mobilizations that seek to end or reverse inequalities in resource relations do so by calling for the restoration of resource sovereignties. Thus, efforts to combat violence that sustains the expansion of territories and the extraction of resources are integrally linked to questions of shifting identities and the implementation of visions for more just and equitable forms of social organization. In the collective efforts detailed above, for example, new alliances and modes of cooperation had been formed, linking previously disparate communities separated by social and geographical differences.

The anti-hailstone cannons that fuelled conflict in the Alpamalag valley represent not only a striking example of overreach or desire for environmental control on the part of the plantations. They also reveal the unfinished relations of inequality and marginalization in the region that made their installation possible. Even as abandoned objects that had been dismantled and had disappeared, the cannons continued to exert an affective presence and unwittingly drew attention to the acts of expansion and impunity that they epitomized. In this sense they resemble rubble, bearing the imprint of the past, but not as a wound - instead revealing successive layers and acts of destruction and, in doing so, undermining any sense that the resource relations they reflect are fixed or given (Gordillo 2014) - rather, those resource relations are "made" and not "found" (Stoler 2008). Despite the dominant forms of socio-political organization in Cotopaxi resembling colonial ruins and the effects of such ruination being felt as keenly as ever, the excessive reach of the cannons also reveals an underlying fragility to these conditions. Even if not immediately changed, they can readily and unexpectedly be exposed - as in how technical arguments about drought causation reintroduced issues of water justice issues within local political discourse.

Another consequence of reading the cannons as rubble moves beyond this observation that evidence of inequalities in the region is to be found not only in extant material relations and differential access to land and water but also in diverse objects, including some in their absence. Brought into focus is something that many local struggles, in Cotopaxi and elsewhere, have long asserted: that placing limits on particularly expansive or destructive practices (as epitomized by the plantations' cannons) is by itself insufficient to address long-standing resource inequalities or to achieve convincing redistribution. Doing so instead requires exposing and altering how colonial ruins of different kinds continue to enable some livelihoods and agricultural practices while severely restricting (or ruining) others. In this light, resisting ruination and restoring resource sovereignties are actions that disrupt ongoing histories of inequality and assert more inclusive modes of cooperating and shaping landscapes. Such actions also offer analytical tools for understanding and interrogating diverse environmental conflicts: extending perspectives on struggle beyond 
oppositional politics to include broader socioecological relations; and maintaining a systemic framing of instances of environmental damage and recovery as evidence of persistent politico-economic formations.

\section{References}

Acosta, A. 2010. A modo de prólogo: soberanías, una propuesta plural. In A. Acosta and M. Martínez (eds.) Soberanías. Quito: Ediciones Abya-Yala. Pp. 7-48.

Aradhana, S. 2006. Introduction: rethinking theories of the state in an age of globalization. In S. Aradhana and A. Gupta (eds.). The anthropology of the state: a reader. Oxford: Blackwell.

Arce, A., S. Sherwood, and M. Paredes. 2015. Repositioning food sovereignty: between Ecuadorian nationalist and cosmopolitan politics. In A. Trauger (ed.). Food sovereignty in international context: discourse, politics and practice of place. London: Routledge.

Bebbington, A.J. 2009. The new extraction: rewriting the political ecology of the Andes? NACLA report on the Americas 42(5): 12-20.

Bebbington, A.J., T. Bornschlegl and A. Johnson. 2013. Political economies of extractive industry: from documenting complexity to informing current debates. Development and Change Virtual Issue 2.

Biolsi, T. 2005. Imagined geographies: sovereignty, indigenous space, and American Indian struggle. American Ethnologist 32(2): 239-259.

Bretón, V. 2015. Tempest in the Andes? Part 1: agrarian reform and peasant differentiation in Cotopaxi (Ecuador). Journal of Agrarian Change 15(1): 89-115.

Burke, B. and B. Shear. 2014. Introduction: engaged scholarship for non-capitalist political ecologies. Journal of Political Ecology 21: 127-144.

Carrera, J. 2010. La soberanía alimentaria en la Constitución Conceptos e implicaciones. In A. Acosta and M. Martínez (eds.). Soberanías. Quito, Ecuador: Ediciones Abya-Yala. Pp. 75-90.

CN. 2016a. Prefectura pide captar fotos y videos de presunto 'bombardeo a la nubes'. Cotopaxi Noticias.

CN. 2016b. El bajo precio de la leche y la sequía motivan protesta de miles de campesinos. Cotopaxi Noticias.

Colloredo-Mansfeld, R. 2009. Fighting like a community: Andean civil society in an era of Indian uprisings. Chicago: University of Chicago Press.

Creativos, 2016. Tres comisiones para vigilar a las brocoleras, el precio de la leche y la redistribución del agua. Cotopaxi Noticias.

EI. 2016. Prefecto de Cotopaxi pide declarar en emergencia a provincia tras sequía que afecta productos de consumo en Semana Santa. Ecuador Inmediato. 23 April. Ecuador.

El Comercio, 2009. Protesta por el uso de antigranizo en Cotopaxi. 4 March. Ecuador.

El Telégrafo, 2016. Técnico del Inamhi descartó que la sequía sea provocada. 7 March. Ecuador.

Expreso, 2016. En Cotopaxi indagan el bombardeo de las nubes. 9 March. Ecuador.

Flores, J. 2009. Cotopaxi, Ecuador y el mundo. Latacunga/Quito: MICC/Instituto de Estudios Ecuatorianos.

FP, 2015. Ecuadorian broccoli export to Russia increases. Fresh Plaza. 30 January.

GADPC. 2015. Actualización del plan de desarrollo y ordenamiento territorial Cotopaxi 2025. Cotopaxi: Gobierno Autónomo Descentralizado de la Provincia de Cotopaxi.

Gómez de la Torre, R. 2016. Carta del lector: la sequía no es responsabilidad de las brocoleras. Cotopaxi Noticias.

Gordillo, G. 2014. Rubble: the afterlife of destruction. Durham N.C.: Duke University Press. Academia, intro

Hoelle J. 2017. Jungle beef: consumption, production and destruction and the development process in the Brazilian Amazon. Journal of Political Ecology 24: 743-762.

Houtart, F. and R.M. Yumbla. 2013. El brócoli amargo. Ciencias Sociales 35: 283-300.

Illescas, Y. 2016. Los campesinos de Cotopaxi marchan porque no llueve. Expreso 4 March. Ecuador. 
INAMHI. 2016. Sequía en la provincia de Cotopaxi podría superarse en los próximos meses. Ecuador: Instituto Nacional de Meteorología e Hidrología.

Kenrick, J. 2011. Scottish land reform and indigenous peoples' rights: self-determination and historical reversibility. Social Anthropology 19(2): 189-203.

La Gaceta, 2016. Director Ejecutivo de Aprofel: 'Es absolutamente falso, que las brocoleras realizan bombardeos a las nubes'. Feb 6. Ecuador.

La Hora, 2016. Verduras y hortalizas escasas por la sequía. 2 March. Ecudor.

Laing, A.F. 2015. Resource sovereignties in Bolivia: re-conceptualising the relationship between Indigenous identities and the environment during the TIPNIS conflict. Bulletin of Latin American Research 34(2): 149-166.

Lane, K. 2003. Haunting the present: five colonial legacies for the new millennium. In N. Whitten (ed.). Millennial Ecuador: critical essays on cultural transformations and social dynamics. Iowa City: University of Iowa.

Latorre, S., K.N. Farrell and J. Martínez-Alier. 2015. The commodification of nature and socioenvironmental resistance in Ecuador: an inventory of accumulation by dispossession cases, 19802013. Ecological Economics 116: 58-69.

Le Gall, J. 2009. El brócoli en Ecuador: la fiebre del oro verde. Anuario Americanista Europeo (6-7): 261288.

Lyons, B.J. 2006. Remembering the hacienda: religion, authority, and social change in highland Ecuador. University of Texas Press.

Maisanche, F. 2016a. Grave sequía destruye los cultivos en Cotopaxi. El Comercio. 4 March. Ecuador.

Maisanche, F. 2016b. Los empresarios de brócoli desmienten el supuesto bombardeo a las nubes. El Comercio. 4 March. Ecuador.

Maisanche, F. 2016c. Indígenas y campesinos protestan por la sequía y el supuesto bombardeo a las nubes en Cotopaxi. El Comercio. 2 March. Ecuador.

Martínez, M. 2010. La soberanía, un mandato constitucional. In A. Acosta and M. Martínez (eds.) Soberanías. Quito, Ecuador: Ediciones Abya-Yala. Pp. 227-238.

Mccreary, T. and V. Lamb. 2014. A political ecology of sovereignty in practice and on the map: the technicalities of law, participatory mapping, and environmental governance. Leiden Journal of International Law 27(3): 595-619. Researchgate

McNeish, J. 2010. Rethinking resource conflict. World Development Report 2011 background paper. Washington D.C.: World Bank.

Partridge, T. 2015. Recoupling groups who resist: dimensions of difference, opposition and affirmation. Journal of Resistance Studies 1(2): 12-50.

Partridge, T. 2016a. Rural intersections: resource marginalisation and the 'non-Indian problem' in highland Ecuador. Journal of Rural Studies 47: 337-349.

Partridge, T. 2016b. Water justice and food sovereignty in Cotopaxi, Ecuador. Environmental Justice 9(2): 49-52. Academia

Pellow, D.N. 2000. Environmental inequality formation toward a theory of environmental injustice. American Behavioral Scientist 43(4): 581-601.

Peña, K. 2015. Social movements, the State, and the making of food sovereignty in Ecuador. Latin American Perspectives 43(1): 221-237.

Powell, D.E. 2015. The rainbow is our sovereignty: rethinking the politics of energy on the Navajo Nation. Journal of Political Ecology 22: 53-78.

Rahier J.M. 2003. Introduction: mestizaje, mulataje, mestiçagem in Latin American ideologies of national identities. Journal of Latin American Anthropology 8(1): 40-51.

Robinson, W.I. 2009. Latin America and global capitalism: a critical globalization perspective. Baltimore: Johns Hopkins University Press. 
Sassen, S. 1998. Globalization and its discontents. New York: New Press. ch.3,5

Stoler, A.L. 2006. On degrees of imperial sovereignty. Public Culture 18(1): 125-146.

Stoler, A.L. 2008. Imperial debris: reflections on ruins and ruination. Cultural Anthropology 23(2): 191-219.

Stoler, A.L. (ed.). 2013. Imperial debris: on ruins and ruination. Durham: Duke University Press.

USAID. 2015. Broccoli farmers get a fair price. Washington D.C.: USAID.

Weismantel, M.J. 1998. Food, gender, and poverty in the Ecuadorian Andes. Prospects Heights: Waveland Press.

Whitten, N. 2003. Introduction. In N. Whitten (ed.). Millennial Ecuador: critical essays on cultural transformations and social dynamics. Iowa City: University of Iowa. Pp. 1-44.

Whitten, N. and D. Whitten. 2011. Histories of the present: people and power in Ecuador. Urbana: University of Illinois Press. 